\title{
Factors Associated with Insufficient Endometrial Sampling in Postmenopausal Women
}

\author{
Postmenopozal Kadınlarda Yetersiz Endometrial Biyopsi Sonucu ile iliş̧kili Faktörler \\ ๑ Seda Ateş, • Ayşe Filiz Gökmen Karasu, • Halime Çalı, • Zeynep Soyman*, \\ ๑ Ömer Uysal**
}

Bezmialem Vakıf University Faculty of Medicine Hospital, Clinic of Gynecology and Obstetrics, Istanbul, Turkey

*istanbul Training and Research Hospital, Clinic of Gynecology and Obstetrics, Istanbul, Turkey

**Bezmialem Vakıf University Faculty of Medicine Hospital, Clinic of Biostatistics, İstanbul, Turkey

\section{Abstract}

Aim: To assess the risk factors associated with high rate of insufficient endometrial sampling on endometrial biopsy in postmenopausal women.

Methods: Data were retrieved from the records of 522 consecutive patients who underwent endometrial sampling. Logistic regression analyses were performed to determine various factors associated with scanty endometrial biopsy. The exclusion criteria included patient refusal, uncertain menopausal status, cervical carcinoma detected after sampling and unavailable records.

Results: The sample was insufficient for a definitive diagnosis in $143(25.9 \%)$ patients. Out of these, 53 cases were investigated with invasive procedures. Further histopathological examination revealed that five (9.4\%) patients had uterine malignancy. Based on the multivariate analysis, time since the onset of menopause [Odds ratio $(\mathrm{OR})=1.044,95 \%$ confidence interval $(\mathrm{Cl})=1.000$ $1.090, p=0.049$ ] was significantly associated with insufficient endometrial biopsy in cases with a endometrial thickness of $>12 \mathrm{~mm}$ on ultrasonography (OR=0.624, 95\% Cl=0.472$0.824, p=0.001)$. The use of dilation and curettage technique ( $\mathrm{OR}=0.662,95 \% \mathrm{Cl}=0.522-0.841, \mathrm{p}=0.001$ ) decreased the risk of insufficient sampling on endometrial biopsy.

Conclusion: Time since the onset of menopause and the thickness of endometrium were significant independent factors associated with insufficient sample. Using Karman cannula for endometrial aspiration may not be a reliable method in the evaluation of postmenopausal women. An insufficient endometrial sample does not rule out endometrial carcinoma, therefore, a further histopathological examination is recommended.

Keywords: Endometrial sampling, insufficient tissue, dilation and curettage, aspiration biopsy, endometrial carcinoma
Amaç: Postmenopozal kadınlarda endometrial biyopsi patoloji sonucunun yetersiz doku olarak saptanması ile ilişkili risk faktörlerini değerlendirmektir.

Yöntemler: Endometrial örnekleme yapılan ardışık 552 hastanın kayıtları incelenerek veriler toplandı. Endometrial örneklemenin yetersizliğine ilişkin faktörleri belirlemek için lojistik regresyon analizleri yapıldı. Hastanın onayının olmaması, belirsiz menapozal durum, örnekleme sonrası serviks kanseri saptanması ve hastanın kayıtlarına ulaşamama dışlanma kriterleri olarak kabul edildi.

Bulgular: Endometrial örneklem $143(\% 25,9)$ hastada kesin tanı için yeterli değildi. Bu vakaların 53'üne invaziv işlem uygulandı. Ek histopatolojik inceleme sonucunda beş $(\% 9,4)$ hastada uterus malignitesi saptandı. Multivariate analiz sonucunda, yetersiz endometrial biyopsi sonuçları ile menopoz başlangıcından itibaren geçen süre $(O R=1,044, \% 95 \mathrm{Cl}=1,000-1,090, p=0,049)$ arasında anlamlı ilişki saptandı. Ultrasonografide endometrial kalınlığın $>12 \mathrm{~mm}$ olması (OR=0,624, \%95 Cl=0,472-0,824, $\mathrm{p}=0,001)$, dilatasyon ve kürtaj tekniğinin uygulanması (OR=0,662, \%95 $\mathrm{Cl}=0,522-0.841, \mathrm{p}=0,001)$ endometrial biyopside yetersiz örnek saptanma riskini azalttığı gösterildi.

Sonuç: Menopoz başlangıcından bu yana geçen süre ve endometrium kalınlığı, yetersiz örneklem ile ilişkili önemli bağımsız faktörlerdir. Endometrial aspirasyon için Karman kanülünün kullanımı, postmenapozal kadınların değerlendirilmesinde güvenilir bir teknik olmayabilir. Yetersiz endometrial örnek endometrial karsinomu ekarte ettirmez, bu nedenle ek bir histopatolojik inceleme önerilir.

Anahtar Sözcükler: Endometrial örnekleme, yetersiz doku, dilatasyon ve küretaj, aspirasyon biyopsisi, endometrial karsinom
Address for Correspondence/Yazışma Adresi: Seda Ateş, Bezmialem Vakıf University Faculty of Medicine Hospital, Clinic of Gynecology and Obstetrics, İstanbul, Turkey E-mail: drsedaates@yahoo.com ORCID: orcid.org/0000-0003-0472-3727

Received/Geliş Tarihi: 29 August 2019 Accepted/Kabul Tarihi: 23 November 2019
${ }^{0}$ Copyright 2020 by The Medical Bulletin of istanbul Haseki Training and Research Hospital The Medical Bulletin of Haseki published by Galenos Yayınevi. ${ }^{\circledR}$ Telif Hakkı 2020 İstanbul Haseki Eğitim ve Araşıırma Hastanesi Haseki Tıp Bülteni, Galenos Yayınevi tarafından yayınlanmıştır. 


\section{Introduction}

Endometrial carcinoma (EC) is the most common gynecologic malignancy in developed countries and the majority of cases are observed in postmenopausal women $(1,2)$. Early detection of EC leads to better prognosis in affected patients (3). Thus, postmenopausal bleeding or increased endometrial thickness requires prompt and efficient investigation to rule out EC in postmenopausal women $(4,5)$. Evaluation of endometrial histology is still the gold standard for diagnosing endometrial pathology. Various endometrial sampling techniques are used to reveal these pathologies. Traditionally, dilation and curettage (D\&C) have been used as a standard method of assessing the endometrium (6). Many alternative techniques with different vacuum equipment such as Pipelle, Vabra or Karman endometrial vacuum aspiration devices have been developed to obtain endometrial biopsies $(7,8)$. The Karman aspirator is an endometrial sampling device that can be used to terminate early pregnancy but it is also an effective and acceptable method for the diagnosis of endometrial pathology (9).

An increased incidence of EC underlines the importance of obtaining sufficient endometrial tissue for early diagnosis (10). There is continuing debate about whether to perform further investigations such as repeating the procedure, hysteroscopy or simply to accept the result as negative when endometrial sampling reveals insufficient tissue for histopathological diagnosis $(11,12)$.

Our study aimed to determine the factors associated with high rate of insufficient endometrial sampling in postmenopausal women. We also analyzed the final histopathological diagnosis following further investigation.

\section{Methods}

\section{Study Design}

We performed a retrospective review of consecutive postmenopausal women who attended the Department of Obstetrics and Gynecology, Bezmialem Vakıf University, İstanbul, Turkey, from January 2012 to May 2018. We reviewed medical records of 614 postmenopausal patients, who underwent endometrial sampling due to either postmenopausal bleeding or incidental finding of increased endometrial thickness on ultrasound, were included in this study. Of these, 35 women were excluded due to patient refusal, 20 due to an uncertain menopausal status, four due to discovery of cervical carcinoma after sampling and three women were excluded because of unavailable records. The remaining 552 medical records were available for analysis.

Postmenopausal bleeding was defined as any vaginal bleeding after an absence of menses for $\geq 12$ months. The study was approved by the Medical Ethics Committee of the Faculty of Medicine of Bezmialem Vakıf University (approval no: 19/243).

\section{Preprocedural Assessment}

The following data were collected: age, years since onset of menopause, body mass index (BMI), history of smoking, presence of hypertension, diabetes and, thyroid disease, use of medication including hormone replacement therapy, anticoagulants, tamoxifen, gravidity, parity, history of vaginal delivery, history of cesarean section, history of curettage or abortion, endometrial thickness on ultrasound, indication for endometrial biopsy, the endometrial sampling technique and endometrial histopathology results.

Endometrial assessment by vaginal ultrasonography before endometrial sampling was performed in 524 of 552 patients. Endometrial thickness was measured as the thickest part in the longitudinal plane, and the measurements included both endometrial layers. Ultrasound scans were performed using a Logiq A5 (General Electric, Milwaukee WI, USA) with an 8-MHz transvaginal transducer. If the endometrial fluid was present, the thickness of the two endometrial layers was measured and the sum was recorded. When the endometrial thickness could not be seen, it was recorded as "non-measurable."

All samples were evaluated by pathologists specialized in gynecology. The sample was considered insufficient if the pathology was reported as "no endometrial tissue is present for evaluation", "insufficient material for diagnosis", "endocervical tissue only" or "blood and/or cervical mucus only."

\section{Endometrial Biopsy Technique}

Endometrial samplings were taken with D\&C or Karman cannula under general anesthesia. Karman aspiration device is a negative pressure vacuum device consisting of a $4 \mathrm{~mm}$ cannula and a $50 \mathrm{cc}$ suction syringe.

All endometrial biopsies were performed by resident physicians under the supervision of attending physicians. Patients with insufficient endometrial samples for histopathological diagnosis underwent further investigations which comprised repeat ultrasonography imaging, repeat endometrial sampling, hysteroscopy or hysterectomy.

The patients were classified according to the histopathological findings. Histopathological diagnoses were determined according to the World Health Organization criteria (13). Normal endometrium included inactive endometrium, proliferative endometrium, secretory endometrium and atrophic endometrium. "Endometrial hyperplasia without atypia" group involved simple and complex hyperplasia without atypia. Simple 
and complex hyperplasia with atypia was included in "endometrial hyperplasia with atypia" group.

\section{Statistical Analysis}

Data were expressed as mean \pm SD or the percentage of the number of subjects. All analysis was performed using the IBM SPSS Statistics, v.20.0 (Armonk, NY: IBM Corp.). Univariate binary logistic regression analysis was performed to determine the various factors regarding the insufficiency of endometrial sampling. Categorical variables were compared using the chi-square or Fisher's exact test. Continuous variables were compared using the independent-samples t-test. A multivariable binary logistic regression analysis was performed to evaluate the independent effect of the tested variables. Variables were included if the $p$ value in the univariate analysis was $<0.1$. A $p$ value of less than $<0.05$ was considered statistically significant.

\section{Results}

The baseline characteristics of all the patients are presented in Table 1. An insufficient sample for histopathological diagnosis was obtained in 85 women $(59.9 \%)$ by D\&C and in 57 women (40.1\%) by Karman cannula aspiration. Three hundred and thirty-one (81.3\%) of the samples which were obtained by D\&C and 76 $(18.7 \%)$ which were obtained by Karman cannula were sufficient. The sample was insufficient for a definitive diagnosis in 143 patients (25.9\%). Out of these, 53 cases were further investigated with invasive procedures which consisted of 25 repeat sampling, 10 hysteroscopies and 18 hysterectomies. Further histopathological examination revealed that five patients (9.4\%) had uterine malignancy. Four cases were endometrioid adenocarcinoma and one case was papillary serous carcinoma. Fourteen (26.4\%) had endometrial polyps and 31 (58.5\%) had benign pathology. Flow diagram of diagnostic workup and final

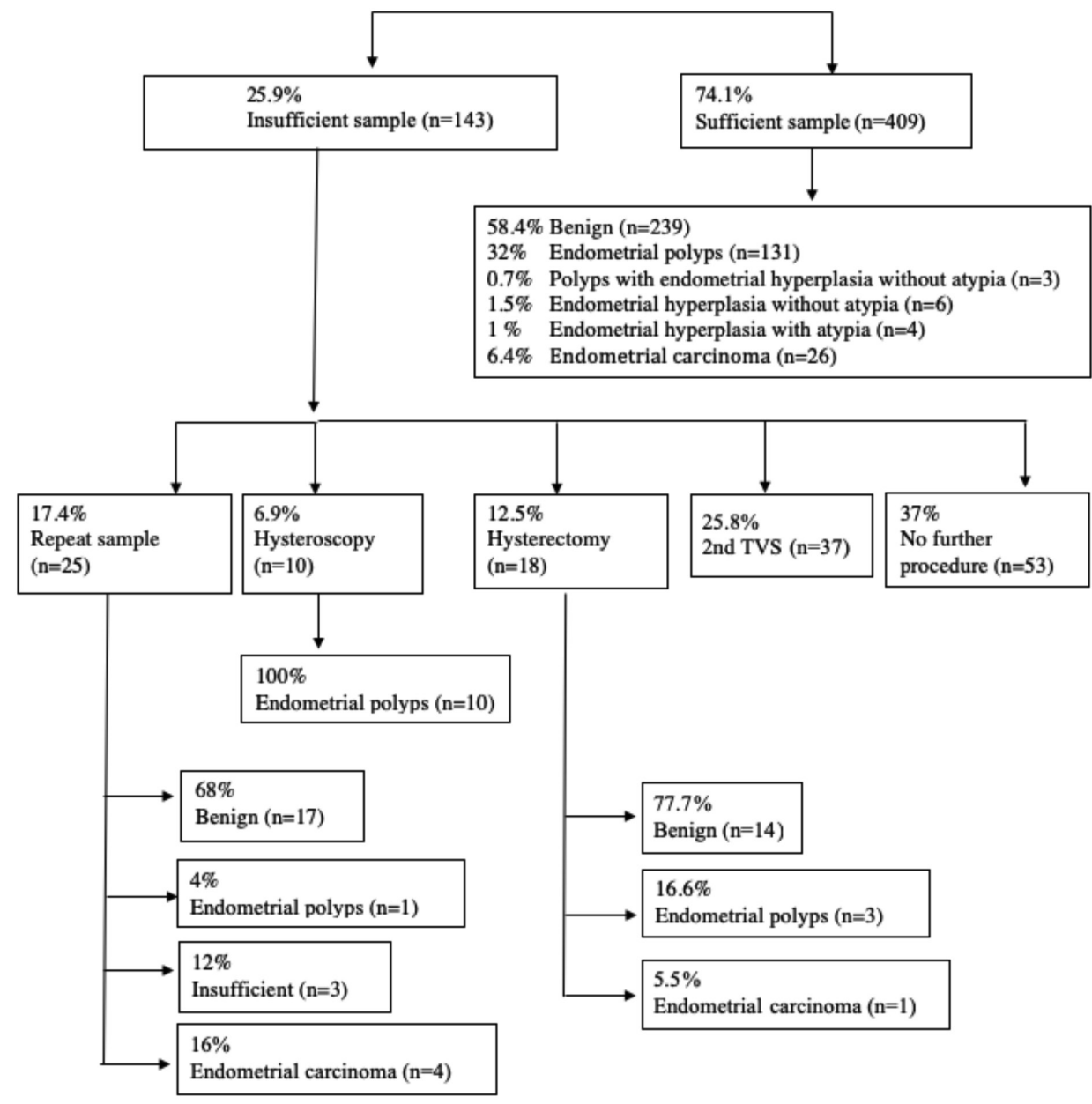

Figure 1. Flow diagram of diagnostic work-up and final diagnosis in 552 postmenopausal women presenting with or without uterine bleeding

TVS: Transvaginal scan, $n$ : Number 
diagnosis of the patients are described in Figure 1. Only one complication (uterine perforation) occurred in four patients who had undergone endometrial sampling.

The results of univariate and multivariate logistic regression analyses are depicted in Table 2 . In univariate analysis, advanced age (OR=1.029, 95\% Cl=1.0061.053, $p=0.016)$, years since onset of menopause
(OR=1.040, 95\% $\mathrm{Cl}=1.017-1.063, \mathrm{p}<0.001)$ and, cervix with a pinpoint external os $(\mathrm{OR}=2.435,95 \% \mathrm{Cl}=1.209$ 4.901, $p=0.005$ ) were all associated with increased risk of insufficient sample on endometrial biopsy. A history of previous vaginal delivery $(\mathrm{OR}=0.664,95 \% \mathrm{Cl}=0.515$ $0.855, \mathrm{p}=0.001)$, endometrial thickness above $12 \mathrm{~mm}$ on ultrasonography $(\mathrm{OR}=0.590,95 \% \mathrm{Cl}=0.459-0.760$,

\begin{tabular}{|c|c|c|c|}
\hline Characteristics & $\begin{array}{l}\text { Insufficient sample on } \\
\text { endometrial biopsy } \\
n=143(26 \%)\end{array}$ & $\begin{array}{l}\text { Sufficient sample on } \\
\text { endometrial biopsy } \\
n=409(74 \%)\end{array}$ & $p$ \\
\hline Age, years; (mean $\pm S D)$ & $60.41 \pm 8.89$ & $58.36 \pm 8.06$ & $0.016^{a}$ \\
\hline $\mathrm{BMI}, \mathrm{kg} / \mathrm{m}^{2} ;($ mean $\pm \mathrm{SD})$ & $30.90 \pm 5.12$ & $30.15 \pm 4.59$ & $0.170^{a}$ \\
\hline Years since the onset of menopause; $n$ & $13.16 \pm 9.35$ & $10.04 \pm 8.37$ & $<0.001^{a}$ \\
\hline Hypertension; n (\%) & $75(52.4 \%)$ & $183(44.9 \%)$ & $0.117^{b}$ \\
\hline Diabetes Mellitus; n (\%) & $42(29.4 \%)$ & $101(24.8 \%)$ & $0.279^{b}$ \\
\hline Thyroid disease; n (\%) & $20(14 \%)$ & $57(14 \%)$ & $0.996^{b}$ \\
\hline Anticoagulant use; n (\%) & $3(2.1 \%)$ & $3(0.7 \%)$ & $0.183^{c}$ \\
\hline Hormone therapy use; n (\%) & $0(0 \%)$ & $3(0.7 \%)$ & $0.572^{c}$ \\
\hline Tmx use; n (\%) & $7(4.9 \%)$ & $20(4.9 \%)$ & $0.998^{b}$ \\
\hline Smoking; n (\%) & $13(9.1 \%)$ & $24(5.9 \%)$ & $0.187^{b}$ \\
\hline \multicolumn{3}{|l|}{ Gravida; n (\%) } & \multirow{4}{*}{$0.072^{b}$} \\
\hline 0 & $2(1.4 \%)$ & $22(5.4 \%)$ & \\
\hline $1-4$ & $80(56.3 \%)$ & $239(59 \%)$ & \\
\hline$\geq 5$ & $60(42.3 \%)$ & $144(35.6 \%)$ & \\
\hline \multicolumn{3}{|l|}{ Parite; n (\%) } & \multirow{4}{*}{$0.093^{b}$} \\
\hline 0 & $15(10.6 \%)$ & $24(5.9 \%)$ & \\
\hline $1-4$ & $94(66.2 \%)$ & $301(74.3 \%)$ & \\
\hline$\geq 5$ & $33(23.2 \%)$ & $80(19.8 \%)$ & \\
\hline Previous intrauterine procedure $(\mathrm{s}) *$; $(\%)$ & $72(50.3 \%)$ & $179(44.2 \%)$ & $0.204^{b}$ \\
\hline History of vaginal delivery; $\mathbf{n}(\%)$ & $112(78.3 \%)$ & $361(89.1 \%)$ & $0.001^{b}$ \\
\hline History of cesarean section; $\mathbf{n}(\%)$ & $21(14.7 \%)$ & $49(12.1 \%)$ & $0.426^{b}$ \\
\hline \multicolumn{4}{|l|}{ Indications for endometrial sampling; n (\%) } \\
\hline Postmenopausal bleeding & $75(52.4 \%)$ & $224(54.8 \%)$ & \multirow[t]{2}{*}{$0.632^{b}$} \\
\hline Increased endometrial thickness on ultrasound (without bleeding) & $68(47.6 \%)$ & $185(45.2 \%)$ & \\
\hline Pinpoint cervical os; $\mathbf{n}(\%)$ & $6(4.2 \%)$ & $3(0.7 \%)$ & $0.005^{b}$ \\
\hline \multicolumn{4}{|l|}{ Endometrial thickness; $\mathbf{n}(\%)$} \\
\hline Not measurable & $4(3.1 \%)$ & $9(2.3 \%)$ & \multirow{4}{*}{$<0.001^{b}$} \\
\hline$\leq 8 \mathrm{~mm}$ & $78(60 \%)$ & $160(40.6 \%)$ & \\
\hline $8-12 \mathrm{~mm}$ & $31(23.8 \%)$ & $114(28.9 \%)$ & \\
\hline$>12 \mathrm{~mm}$ & $17(13.1 \%)$ & $111(28.2 \%)$ & \\
\hline \multicolumn{4}{|l|}{ Endometrial sampling method; $n$ (\%) } \\
\hline$D \& C$ & $85(59.9 \%)$ & $331(81.3 \%)$ & \multirow[t]{2}{*}{$<0.001^{b}$} \\
\hline Karman cannula aspiration & $57(40.1 \%)$ & $76(18.7 \%)$ & \\
\hline
\end{tabular}


$p<0.001)$ and endometrial samples obtained by $D \& C$ (OR=0.585, 95\% Cl=0.475-0.721, $\mathrm{p}<0.001$ ) decreased the likelihood of insufficient sampling.

Multiple regression analysis further revealed that only years since the onset of menopause $(O R=1.044$, 95\% $\mathrm{Cl}=1.000-1.090, \mathrm{p}=0.049)$ remained significantly associated with insufficient endometrial biopsy results while advanced age, history of previous vaginal delivery and cervix with a pinpoint external os did not reach statistical significance. This analysis also demonstrated that an endometrial thickness of $>12 \mathrm{~mm}$ on ultrasonography (OR=0.624, 95\% Cl=0.472-0.824, $\mathrm{p}=0.001)$ and use of the $\mathrm{D} \& \mathrm{C}$ technique $(\mathrm{OR}=0.662,95 \% \mathrm{Cl}=0.522-0.841$, $\mathrm{p}=0.001)$ significantly decreased the risk of insufficient sample on endometrial biopsy.

\section{Discussion}

In this study, among 552 postmenopausal women who underwent endometrial sampling, 25.9\% (144) had insufficient samples for a definitive histopathological diagnosis. This result is in accordance with the previously published studies which reported that the rate of insufficient samples varies between $16 \%$ and $50 \%(11,14-$ 16).

Factors affecting the risk of an insufficient sample have been rarely investigated. Based on the literature, the chance of obtaining a sufficient sample is positively associated with endometrial thickness (17). Bakour et al. (18) reported that an endometrial thickness of $<5 \mathrm{~mm}$ on ultrasonography and hysteroscopic finding of endometrial atrophy were important factors associated with insufficient sampling. Consistent with our findings, several authors reported that the chance of getting an adequate sample was increased in postmenopausal women with an endometrial thickness of $>12 \mathrm{~mm}$, and they also suggested that nulliparity and advanced age were independent factors affecting unsuccessful Pipelle sampling (15). A recent study reported that an endometrial thickness of less than $8 \mathrm{~mm}$ and menopausal status were associated with an increased risk of insufficient endometrial sampling (19).

In our study, we showed that time since onset of menopause was significantly associated with a high risk of insufficient samples on endometrial biopsy. Piątek et al. (20) revealed that the highest rate of nondiagnostic Pipelle biopsy sample was found in post-menopausal women (38.46\%) and women over 55 years of age $(41.33 \%)$. Several studies reported that menopausal status was associated with an insufficient sample on endometrial biopsy due to postmenopausal atrophic endometrium which leads to scant endometrial tissues for pathologic evaluation (18,21-23). In their study, Kim et al. (24) compared the diagnostic accuracy of D\&C with endometrial aspiration biopsy in patients treated with highdose progestin and levonorgestrel-releasing intrauterine system (LNG-IUS) for early-stage endometrial cancer. They suggested that the high percentage of insufficient samples was due to LNG-IUS-induced endometrial atrophy as in postmenopausal status.

Our results demonstrated that D\&C is significantly more likely to yield a sufficient endometrial sample for histopathological diagnosis than the use of Karman

\begin{tabular}{|c|c|c|c|c|}
\hline \multicolumn{5}{|c|}{ Dependent variables (insufficient sample $=1$ vs sufficient sample $=0$ ) } \\
\hline \multirow[t]{2}{*}{ Independent variables } & \multicolumn{2}{|l|}{ Univariate analysis } & \multicolumn{2}{|l|}{ Multivariate analysis* } \\
\hline & OR $(95 \% \mathrm{Cl})$ & p & OR $(95 \% \mathrm{Cl})$ & p \\
\hline Age, years & $1.029(1.006,1.053)$ & 0.016 & $0.985(0.941,1.032)$ & 0.535 \\
\hline Years since the onset of menopause & $1.040(1.017,1.063)$ & $<0.001$ & $1.044(1.000,1.090)$ & 0.049 \\
\hline \multicolumn{5}{|l|}{ Parite } \\
\hline 0 & - & - & - & - \\
\hline $1-4$ & $0.723(0.537,0.974)$ & \multirow{2}{*}{0.093} & $1.009(0.667,1.527)$ & 0.965 \\
\hline$\geq 5$ & $0.955(0.671,1.361)$ & & $1.260(0.744,2.133)$ & 0.390 \\
\hline History of vaginal delivery & $0.664(0.515,0.855)$ & 0.001 & $0.66(0.433,1.006)$ & 0.053 \\
\hline Pinpoint cervical os & $2.435(1.209,4.901)$ & 0.005 & $1.593(0.675,3.758)$ & 0.288 \\
\hline $\begin{array}{l}\text { Endometrial thickness } \\
\text { ( } \leq 8 \text { vs } 8-12 \text { vs }>12 \mathrm{~mm} \text { ) }\end{array}$ & $0.590(0.459,0.760)$ & $<0.001$ & $0.624(0.472,0.824)$ & 0.001 \\
\hline $\begin{array}{l}\text { Endometrial sampling method } \\
\text { (D\&C vs Karman cannula aspiration) }\end{array}$ & $0.585(0.475,0.721)$ & $<0.001$ & $0.662(0.522,0.841)$ & 0.001 \\
\hline
\end{tabular}


cannula aspiration. In the present study, the sufficiency of the tissue sample taken with D\&C was found to be $79.5 \%$ which is less than in previous reports $(25,26)$. In a study by Tanriverdi et al. (27), D\&C and Pipelle sampling were compared, and an $88.1 \%$ sufficient sample rate in D\&C and $77.2 \%$ for Pipelle were reported. They also demonstrated the limitation of the Pipelle in yielding a sufficient endometrial tissue particularly in postmenopausal women. Tansathit et al. (9) reported an $86.7 \%$ sufficient sample rate using Karman cannula in women presenting with abnormal uterine bleeding, which is higher than in our study. It may be due to the fact that most of the patients in their study were premenopausal (77.4\%). They also reported that Karman cannula missed EC diagnosis in 11 cases. This was correlated with the inability of Karman cannula to create a negative pressure in the uterine cavity. They stated that although the endometrial aspiration with the Karman cannula seems to be a simple and inexpensive technique for detecting endometrial pathology, they offer other investigations such as hysteroscopy for patients in whom creation of negative pressure in the uterus is unsuccessful or who still have further uterine bleeding with undetermined endometrial pathology.

We found no significant association between insufficient samples and the factors that affect insufficient biopsy results including BMI, nulliparity, use of hormone replacement therapy and indications for the biopsy which is in contrast to the results of previous reports $(15,20,22,28,29)$.

After further investigation of insufficient samples, we found five $(9.4 \%)$ cases of EC in accordance with other studies. Van Doorn et al. (11) reported that in 66 postmenopausal women with the result of insufficient outpatient endometrial sampling, $6 \%$ were found to have a histopathological diagnosis of EC $(n=3)$ or atypical hyperplasia $(\mathrm{n}=1)$ after a second investigation. Visser et al. (15) found six (7.1\%) cases of EC among 84 women who presented with postmenopausal bleeding and whose initial samples were insufficient. In a study performed by Farrell et al. (14), Pipelle endometrial sampling was insufficient in 141 postmenopausal women. Twenty percent of these patients were found to have significant endometrial pathology including four cases of malignancy on follow-up. Our results are in agreement with the previous studies indicating that women with an insufficient sample should undergo a further investigation to rule out EC $(14,16,18)$.

Besides its large sample size, one of the strengths of this study is examining large amount of patient data and the potential risk factors that may lead to insufficient sampling enabling us to determine the predictive impact of various cofactors.

\section{Study Limitations}

The main limitation of our study lies in its retrospective nature and its inherent biases. Other limitation may be accomplishing all endometrial biopsies by resident physicians.

\section{Conclusion}

Our results showed that time since onset of menopause and thickness of endometrium were significant independent factors associated with an insufficient sample for the diagnosis of endometrial pathology. Furthermore, our study suggests that D\&C provides a more sufficient sample for pathological evaluation compared to endometrial aspiration biopsy with Karman cannula in postmenopausal women. Therefore, endometrial aspiration with Karman cannula may not be a reliable technique in the evaluation of postmenopausal women. Furthermore, this study demonstrated that an insufficient endometrial sample does not rule out EC and further histopathological examination is recommended. Future prospective studies are required to clarify the factors associated with a high probability of insufficient endometrial sampling and the best method for evaluation of endometrium in postmenopausal women.

\section{Authorship Contributions}

Concept: S.A. Design: A.F.G.K. Data Collection or Processing: H.Ç. Analysis or Interpretation: Ö.U. Literature Search: Z.S. Writing: S.A.

Conflict of Interest: The authors certify that there is no conflict of interest with any financial organization regarding the material discussed in the manuscript.

Financial Disclosure: The authors certify that there is no conflict of interest with any financial organization regarding the material discussed in the manuscript.

\section{References}

1. Murali R, Soslow RA, Weigelt B. Classification of endometrial carcinoma: more than two types. Lancet Oncol 2014;15:e26878.

2. Siegel R, Ward E, Brawley O, Jemal A. Cancer statistics, 2011: the impact of eliminating socioeconomic and racial disparities on premature cancer deaths. CA Cancer. J Clin 2011;61:21236.

3. Seebacher $V$, Schmid $M$, Polterauer $S$, et al. The presence of postmenopausal bleeding as prognostic parameter in patients with endometrial cancer: a retrospective multi-center study. BMC Cancer 2009;9:460.

4. Goldstein SR. The role of transvaginal ultrasound or endometrial biopsy in the evaluation of the menopausal endometrium. Am J Obstet Gynecol 2009;201:5-11.

5. Osmers RG, Osmers M, Kuhn W. Prognostic value of transvaginal sonography in asymptomatic endometrial cancers. Ultrasound Obstet Gynecol 1995;6:103-7. 
6. Tabata T, Yamawaki T, Ida M, Nishimura K, Nose Y, Yabana T. Clinical value of dilatation and curettage for abnormal uterine bleeding. Arch Gynecol Obstet 2001;264:174-6.

7. Du J, Li Y, Lv S, et al. Endometrial sampling devices for early diagnosis of endometrial lesions. J Cancer Res Clin Oncol 2016;142:2515-22.

8. Dreisler E, Poulsen LG, Antonsen SL, et al; European Menopause and Andropause Society. EMAS clinical guide: assessment of the endometrium in peri and postmenopausal women. Maturitas 2013;75:181-90.

9. Tansathit T, Chichareon S, Tocharoenvanich S, Dechsukhum C. Diagnostic evaluation of Karman endometrial aspiration in patients with abnormal uterine bleeding. J Obstet Gynaecol Res 2005;31:480-5.

10. Sheikh MA, Althouse AD, Freese KE, et al. USA endometrial cancer projections to 2030: should we be concerned? Future Oncol 2014;10:2561-8.

11. Van Doorn HC, Opmeer BC, Burger CW, Duk MJ, Kooi GS, Mol BW; Dutch Study in Postmenopausal Bleeding (DUPOMEB). Inadequate office endometrial sample requires further evaluation in women with postmenopausal bleeding and abnormal ultrasound results. Int J Gynaecol Obstet 2007;99:100-4.

12. Gredmark T, Kvint S, Havel G, Mattsson LA. Histopathological findings in women with postmenopausal bleeding. $\mathrm{Br} \mathrm{J}$ Obstet Gynaecol 1995;102:133-6.

13. Horn LC, Meinel A, Handzel R, Einenkel J. Histopathology of endometrial hyperplasia and endometrial carcinoma: an update. Ann Diagn Pathol 2007;11:297-311.

14. Farrell T, Jones N, Owen P, Baird A. The significance of an 'insufficient' Pipelle sample in the investigation of post-menopausal bleeding. Acta Obstet Gynecol Scand 1999;78:810-2.

15. Visser NC, Breijer MC, Herman MC, et al. Factors attributing to the failure of endometrial sampling in women with postmenopausal bleeding. Acta Obstet Gynecol Scand 2013;92:1216-22.

16. Van Hanegem N, Prins MM, Bongers MY, Opmeer BC, Sahota DS, Mol BW, et al. The accuracy of endometrial sampling in women with postmenopausal bleeding: a systematic review and meta-analysis. Eur J Obstet Gynecol Reprod Biol 2016;197: 147-55.

17. Elsandabesee D, Greenwood P. The performance of Pipelle endometrial sampling in a dedicated postmenopausal bleeding clinic. J Obstet Gynaecol 2005;25:32-4.
18. Bakour SH, Khan KS, Gupta JK. Controlled analysis of factors associated with insufficient sample on outpatient endometrial biopsy. BJOG 2000;107:1312-4.

19. Aue-Aungkul A, Kleebkaow P, Kietpeerakool C. Incidence and risk factors for insufficient endometrial tissue from endometrial sampling. Int J Womens Health 2018; 10:453-7.

20. Piątek S, Panek G, Wielgoś M. Assessment of the usefulness of pipelle biopsy in gynecological diagnostics. Ginekol Pol 2016;87:559-64.

21. van Hanegem N, Breijer MC, Khan KS, et al. Diagnostic evaluation of the endometrium in postmenopausal bleeding: an evidence-based approach. Maturitas 2011;68:155-64.

22. Williams AR, Brechin S, Porter AJ, Warner P, Critchley HO. Factors affecting adequacy of Pipelle and Tao Brush endometrial sampling. BJOG 2008;115:1028-36.

23. Xie B, Qian C, Yang B, et al. Risk Factors for Unsuccessful OfficeBased Endometrial Biopsy: A Comparative Study of OfficeBased Endometrial Biopsy (Pipelle) and Diagnostic Dilation and Curettage. J Minim Invasive Gynecol 2018;25:724-9.

24. Kim MK, Seong SJ, Song T, et al. Comparison of dilatation \& curettage and endometrial aspiration biopsy accuracy in patients treated with high-dose oral progestin plus levonorgestrel intrauterine system for early-stage endometrial cancer. Gynecol Oncol 2013;130:470-3.

25. Sanam M, Majid MM. Comparison the Diagnostic Value of Dilatation and Curettage Versus Endometrial Biopsy by Pipelle-a Clinical Trial. Asian Pac J Cancer Prev 2015;16:49715.

26. Demirkiran F, Yavuz E, Erenel H, Bese T, Arvas M, Sanioglu C. Which is the best technique for endometrial sampling? Aspiration (pipelle) versus dilatation and curettage (D\&C). Arch Gynecol Obstet 2012;286:1277-82.

27. Tanriverdi HA, Barut A, Gün BD, Kaya E. Is pipelle biopsy really adequate for diagnosing endometrial disease? Med Sci Monit 2004;10:CR271-4.

28. Adambekov S, Goughnour SL, Mansuria S, et al. Patient and provider factors associated with endometrial Pipelle sampling failure. Gynecol Oncol 2017;144:324-8.

29. Piatek S, Warzecha D, Kisielewski F, Szymusik I, Panek G, Wielgos M. Pipelle biopsy and dilatation and curettage in clinical practice: are factors affecting their effectiveness the same? J Obstet Gynaecol Res 2019;45:645-51. 